Monjed, H. and Ibrahim, S. (2020), "Risk disclosure, income smoothing and firm risk", forthcoming in Journal of Applied Accounting Research

https://doi.org/10.1108/JAAR-05-2019-0085

Supplied under an Attribution-NonCommercial 4.0 International Licence https://creativecommons.org/ licenses/by-nc/4.0/

This author accepted manuscript is deposited under this licence and that any reuse is allowed in accordance with the terms outlined by the licence. 


\title{
Risk Disclosure, Income Smoothing and Firm Risk
}

\begin{abstract}
Purpose: Evidence on whether firms with higher risk choose a more transparent or more opaque risk reporting strategy in their annual reports is mixed. A potential explanation is that firms choose an alternative reporting strategy to risk disclosure, namely income smoothing. The purpose of this paper is to investigate the association between both strategies in relation to firm risk levels.

Design/Methodology: We use a balanced sample of 74 non-financial UK firms from the FTSE100 index over the period 2005-2015, examining the association between firm risk measures and both risk disclosure and income smoothing using a seemingly unrelated regression methodology.

Findings: We find that firm financial risk measures are positively associated with both risk disclosure and income smoothing, implying a complementary association. Furthermore, non-risk related factors are associated with both lower levels of risk disclosure and higher income smoothing, implying a substitutive effect.
\end{abstract}

Research limitations: We do not consider other factors such as managerial optimism, managerial financial incentives and analysts' earnings forecasts which might influence the association between risk disclosure and income smoothing and hence this may be a limitation of the current study.

Practical implications: These results are important to regulators, investors and boards of directors who are interested in understanding the alternative reporting strategies that managers select when faced with high risk. The findings signal a need for closer regulatory scrutiny on not only the level of risk disclosure but the financial reporting choices.

Originality/Value: We extend the literature on the reporting vs. recognition decisions made by managers.

Keywords: Risk disclosure; Income smoothing; Firm risk; Textual analysis

JEL Codes : M10 ; M41 ; G32 


\section{Introduction}

Evidence on whether firms with higher risk choose a more transparent or more opaque risk reporting strategy in their annual reports is mixed (Linsley and Shrives, 2005, 2006; Marshall and Weetman, 2007; Elzahar and Hussainey, 2012; Elshandidy et al., 2013). A potential explanation is that firms choose an alternative reporting strategy to risk disclosure, namely income smoothing, given that firms with smoother income are perceived as being less risky (Graham et al., 2005).

Prior literature documents that firms often use disclosure and recognition practices (earnings reporting) as substitutes. For example, firms with higher overall disclosure quality (Lobo and Zhou, 2001; Mouselli et al., 2012; Katmon and Al Farooque, 2017), greater disclosure frequency (Jo and Kim, 2007) and increased disclosure transparency (Cassell et al., 2015) report lower levels of discretionary accruals in their financial statements. Similarly, firms that voluntarily disclose more information in their annual reports exhibit less use of discretionary accruals to smooth earnings (Lapointe-Antunes et al., 2006). However, some evidence points to disclosure and recognition practices being used as complements. For example, firms with higher levels of voluntary disclosure exhibit a smoother earnings stream (Cox, 1985; Francis et al., 2008). Similarly, firms with higher disclosure quality use discretionary accruals to smooth earnings more aggressively than firms with lower disclosure quality (Shaw, 2003).

In the context of risk reporting, firms with higher risk may choose to increase (not increase) the level of risk reporting as well as report (not report) a smoother stream of income. Therefore, these alternative reporting strategies can be associated in a complementary or substitutive way. We empirically examine whether the level of risk disclosure and income smoothing are complementary/substitutive reporting mechanisms with respect to firm risk levels, using a seemingly unrelated regression methodology. We focus on several measures of risk including: beta, leverage, solvency, liquidity, and operational risks.

Using a sample of FTSE 100 firms with available data over the period 2005-2015, we find that firms' financial risk is positively associated with both risk disclosure and income smoothing. Specifically, firms with higher leverage risk report both smoother income and more risk information, implying a complementary relationship. We also find that non-risk related factors are associated with both lower levels of risk disclosure and higher income smoothing, implying a 
substitutive association. The results are robust to an alternative measure of income smoothing, a further test on the substitutive relation, and in a subsample analysis of high-risk and low-risk firms. This study contributes to several strands of the literature. First, we contribute to the literature examining the association between risk disclosure and firm risk (e.g. Linsley and Shrives, 2005; Marshall and Weetman, 2007; Elshandidy et al., 2013; Khlif and Hussainey, 2016). Whereas this literature examines risk reporting, the current study focuses on a different reporting strategy income smoothing - that firms use alongside risk reporting. Our evidence showing that risk is positively associated with income smoothing is an extension to prior literature. Second, we contribute to the literature examining the association between disclosure and reporting strategies (e.g. Kasznik, 1999; Lobo and Zhou, 2001; Shaw, 2003; Lapointe-Antunes et al., 2006; Jans et al., 2008; Athanasakou and Hussainey, 2014; Cassell et al., 2015; Katmon and Al Farooque, 2017). In particular, our study extends this literature by focusing on an alternative type of disclosure, through risk reporting and documenting that risk disclosure is associated with earnings management. Finally, we contribute to the income smoothing literature by presenting the underlying riskiness of firms as a driver of smoothing behavior (e.g. Grant et al., 2009). In this context, we present further evidence on risk measures such as leverage, solvency and operational risks that are positively associated with income smoothing.

The remainder of the paper is organized as follows. Section 2 provides an overview of the related literature and develops the hypotheses. Section 3 discusses the sample selection and methodology. Section 4 presents the empirical results and discussion. Section 5 presents additional analyses and robustness checks and the last section concludes.

\section{Literature review and hypotheses development}

A firm's risk reporting strategy involves textual risk disclosure of information to the public about the firm's exposure to potential losses and threats which could impact future profitability (Jorgensen and Kirschenheiter, 2003; Kravet and Muslu, 2013). In the UK, risk reporting requirements relate to internal control risks (FRC, 2014), financial risk (International Financial Reporting Standards), and business risk (Companies Act, 2006). However, firms in the UK face no regulation of a specific quantity, template or format for risk disclosure. Therefore, discretion is to some extent inherent in the quantity and quality dimensions of risk disclosure (Dobler, 2008). 
It follows, therefore, that managers may use their discretion to decide on whether to withhold or expand the level of risk information to be communicated to external parties.

Under agency theory, managers provide more disclosure of risk information voluntarily in order to reduce information asymmetry about firms' risk levels, and hence lower agency costs (e.g. Abdullah et al., 2015). Similarly, under signaling theory, managers reduce information asymmetry by signaling firm risk information and risk management policies voluntarily to outsiders in order to distinguish their firms from other firms which disclose less risk information and lack such policies (Elshandidy et al., 2013).

Prior empirical work on textual risk disclosure finds mixed evidence on the association between risk disclosure and firms' risk levels (e.g., Linsley and Shrives, 2005, 2006; Marshall and Weetman, 2007; Dobler et al., 2011; Elzahar and Hussainey, 2012; Elshandidy et al., 2013, 2015; Khlif and Hussainey, 2016). For example, Elshandidy et al. (2013) find that firms provide more risk disclosures as their systematic, financing risk and risk-adjusted returns increase. Khlif and Hussainey (2016) find that firms with higher leverage ratios issue more risk information in order to mitigate creditors' concerns related to the firm's solvency. However, Linsley and Shrives (2005) find that FTSE 100 firms' risk disclosures do not reflect the risks these firms face. This could be because risk disclosures increase firm perceived risk and augment job security concerns (Kravet and Muslu, 2013; Campbell et al., 2014). Based on this discussion, we formulate the first hypothesis as follows:

\section{$H_{1:}$ There is an association between the level of risk disclosure and firm risk.}

A separate strand of research focuses on the incentives of reporting a smooth stream of income in relation to firm risk levels. Agency theory suggests that the internal and external demand for income smoothing could be the equilibrium consequence of optimal contracting (Dye, 1988). The internal demand for income smoothing is driven by the managers' interest to make firms look less risky for job security concerns; whereas the external demand comes from shareholders who prefer to invest in a firm with less earnings volatility. Similarly, signaling theory suggests that firms with asymmetric information can signal private information about managers' assessments of their firm's underlying risk and future prospects by smoothing earnings (Chaney and Lewis, 1995). Firms which smooth income are not only able to signal their higher abilities in managing risk, but also lower the level of firm perceived risk compared to other firms in the same industry (Graham 
et al., 2005; Erickson et al., 2017). Prior empirical evidence shows significant associations between smoothing behavior and firm risk (e.g. Beattie et al., 1994; Tseng and Lai, 2007). Our second hypothesis is therefore formulated as follows:

\section{$\mathrm{H}_{2}$ : There is an association between the extent of income smoothing and firm risk.}

The first two hypotheses examine risk disclosure and income smoothing as stand-alone strategies. However, decisions about both reporting strategies when firms are faced with high risk are expected to be made jointly (Tucker, 2015). Prior evidence investigating overall firm disclosure quality and level alongside recognition practices (through financial statements) implies that both risk disclosure and income smoothing are related.

Some studies find evidence that firms with higher quality or level of disclosure have lower levels of earnings management, implying a substitutive relationship. For example, prior research reports a negative association between accruals-based earnings management and disclosure quality (Lobo and Zhou, 2001; Mouselli et al., 2012; Cassell et al., 2015; Katmon and Al Farooque, 2017). Cassell et al. (2015) find that higher accruals quality (i.e. lower accruals-based earnings management) is associated with more transparent disclosures of valuation allowance and reserve accounts. Mouselli et al. (2012) also find a positive association between accruals quality and disclosure quality. Lapointe-Antunes et al. (2006) find that firms disclosing information voluntarily in the annual report have lower use of discretionary accruals to smooth earnings. Chih et al. (2008) also find that firms providing more information on their corporate social responsibility practices are less likely to smooth reported earnings.

However, other studies find that firms with higher voluntary disclosure have lower earnings volatility, implying a complementary association between voluntary disclosure and income smoothing (Cox, 1985; Francis et al., 2008). Shaw (2003) finds that firms with higher disclosure quality, measured through financial analysts' ratings, smooth reported income through discretionary accruals more aggressively than firms with lower disclosure quality.

In the context of risk reporting, we expect that firms with higher risk may choose to increase (not increase) the level of risk reporting or report (not report) a smoother stream of income. Therefore, these alternative reporting strategies can be associated in a complementary or substitutive way. Under agency theory, Fama and Jensen (1983) argue that not all members of the boards of directors work to improve management's accountability and financial reporting. Furthermore, managers 
may have weaker incentives to reveal information about their firms' risk profile fearing that their fiduciary duty will be subject to more detailed scrutiny and investor litigation (e.g. Leftwich et al., 1981). Therefore, it is possible that managers use their financial reporting choices to mask the firm's underlying volatility and make the firm appear less risky. Under this scenario, we expect that, as firm risk increases, managers will disclose less risk information and report smoother earnings.

However, arguments based on signaling theory suggest that managers use their reporting choices in a way that signals the firm's real underlying risk as well as their honest expectations of the firm's future prospects in order to lower firm perceived risk. In this setting, we expect that managers will report more risk disclosures and smoother earnings as firm risk increases. Given these two alternative predictions, the hypothesis on the relation between risk disclosure and earnings smoothing with respect to firm risk is formulated as follows:

$\mathrm{H}_{3}$ : There is a complementary (substitutive) association between the level of risk disclosure and the extent of income smoothing in relation to firm risk.

\section{Sample selection and methodology}

\subsection{Sample selection}

Our sample consists of firms with at least three consecutive years of listing on the Financial Times Stock Exchange 100 (FTSE100) index in the UK over the period 2005-2015 (similar to studies such as in Linsley and Shrives, 2005 and Abraham and Shrives, 2014). We exclude financial companies as they are subject to a different regulatory framework for disclosure practices. This yields an initial sample of 96 firms. We exclude 22 firms with missing accounting and market data, yielding a final balanced sample of 74 firms with 814 firm-year observations.

Financial data is collected from Bloomberg and Datastream for the financial years 2005-2013. In addition, we obtain annual reports from Thomson ONE, when available, or the firms' websites. In line with prior research, the continuous variables in this study are winsorized at the 1st and 99th percentile values in order to reduce the impact of outliers (Kravet and Muslu, 2013). ${ }^{1}$

\footnotetext{
${ }^{1}$ Our inferences remain unchanged when we only winsorize the continuous explanatory variables.
} 


\subsection{Variables measurement}

\subsubsection{Measurement of risk disclosure (RD)}

Our risk disclosure variable $(R D)$ is measured as the natural logarithm of the total number of sentences containing at least one risk-related keyword. We use an automated content analysis using Nudist 6 to search and count the total number of risk-related sentences, containing at least one risk keyword, in each annual report. ${ }^{2}$ Consistent with prior research, we adopt the sentence unit-ofanalysis approach to identify risk-related sentences in order to avoid multiple counting of the same risk-related information with more than one keyword (Kravet and Muslu, 2013; Elgammal et al., 2018). Appendix 1 presents our final keyword list, consisting of 27 risk-related word roots. The list includes some keywords that are similar to those used in prior studies (e.g., Li, 2006; Kravet and Muslu, 2013; Elshandidy et al., 2013, 2015). Our risk disclosure measure strongly correlates with Li's (2006) and Kravet and Muslu's (2013) with a correlation coefficient of 0.87 and 0.73 , respectively.

\subsubsection{Measurement of income smoothing (IS)}

We measure the extent of income smoothing $(I S)$ by calculating the ratio of a firm's standard deviation of operating income divided by the standard deviation of its cash flow from operations (both deflated by the beginning-of-year total assets) using annual data over the current and past four years' observations (e.g., Leuz et al., 2003). We multiply the measure by minus one so that higher values correspond to higher levels of income smoothing.

We alternatively use $I S \_C o r r$, measured as the correlation between changes in accounting accruals and changes in cash flows from operations (both deflated by total assets), over a five-year period (e.g., Leuz et al., 2003). We calculate accruals from the cash flow statement in line with Hribar and Collins (2002). We also multiply this measure by minus one so that higher values correspond to higher levels of income smoothing.

\subsubsection{Measurement of firm risk levels}

Our independent variables include firm market-risk and accounting-risk measures: Beta, Leverage, Solvency, Liquidity, and Op_Risk. We first use beta (Beta) as a market-risk measure to assess

\footnotetext{
${ }^{2}$ Nudist 6 is a text analysis package used in several studies on corporate textual disclosure (e.g., Hussainey et al., 2003).
} 
firms' systematic risk (e.g. Beattie et al., 1994; Linsley and Shrives, 2006). Beta is estimated using market model regressions of firms' monthly stock returns on the value weighted market index, over a five-year period.

We use leverage and asset coverage ratios to measure financial risk (e.g., Carlson and Bathala, 1997; Linsley and Shrives, 2006; Marshall and Weetman, 2007; Tseng and Lai, 2007; Elshandidy et al., 2013). The leverage ratio (Leverage) is calculated by dividing total debt by total equity. The asset coverage ratio (Solvency) is calculated by dividing the difference between net assets and net liabilities by total liabilities. We use the reciprocal of the leverage and coverage ratios, so that higher values indicate higher financial risks.

We also include liquidity risk, Liquidity, (e.g., Shen and Chih, 2005; Marshall and Weetman, 2007; Elshandidy et al., 2013) calculated as the reciprocal of the current ratio. Finally, we use operational risk $\left(O p \_R i s k\right)$ which is a firm-specific risk arising from changes in the firm's operating cash flows (Markarian and Gill-de-Albornoz, 2012).Op_Risk is the standard deviation of operating cash flows deflated by total assets, estimated using annual data over a five-year period.

\subsection{Empirical model}

To account for simultaneity between risk disclosure and income smoothing, we use a simultaneous equation system by employing seemingly unrelated regressions (SUR), similar to Abernethy et al. (2015). We first estimate SUR regressions for each financial reporting choice to determine whether both reporting choices are related to firm risk measures. Risk disclosure and income smoothing are considered complements (substitutes) when the coefficients of similar risk measures are significantly related to both reporting choices with similar (different) signs.

Then, we run correlational tests of the residuals of the regressions. Risk disclosure and income smoothing are considered complements (substitutes) when the correlation between the error terms is significant and positive (negative). The error terms represent the unexplained portions of the variation in risk disclosure and income smoothing resulting from omitted variables related to both reporting choices. The SUR is estimated using the following equations on a pooled time-series, cross-sectional basis: 


$$
\begin{aligned}
& R D_{i t}=\beta_{0}+\beta_{1} \text { Beta }_{i t}+\beta_{2} \text { Leverage }_{i t}+\beta_{3} \text { Solvency }_{i t}+\beta_{4} \text { Liquidity }_{i t}+\beta_{5} O p_{\_} \text {Risk }_{i t}+ \\
& \beta_{6} \text { RAR }_{i t}+\beta_{7} \text { Size }_{i t}+\beta_{8} \text { Growth }_{i t}+\beta_{9} \text { Profitability }_{i t}+\beta_{10} \text { Dividend }_{i t}+ \\
& \beta 11 \text { Cross_Listing }{ }_{i t}+\beta_{12} \text { Ind_Directorsit }+\beta_{13} \text { Analystsit }+\varepsilon i t \\
& I S_{i t}=\beta_{0}+\beta_{1} \text { Beta }_{i t}+\beta_{2} \text { Leverage }_{i t}+\beta_{3} \text { Solvency }_{i t}+\beta_{4} \text { Liquidity }_{i t}+\beta_{5} O p_{-} \text {Risk }_{i t}+ \\
& \beta_{6} \text { RAR }_{i t}+\beta_{7} \text { Size }_{i t}+\beta_{8} \text { Growth }_{i t}+\beta_{9} \text { Profitability }_{i t}+\beta_{10} \text { Dividend }_{i t}+ \\
& \beta_{11} \text { Cross_Listing }{ }_{i t}+\beta_{12} \text { Ind_Directorsit }+\beta_{13} \text { Analysts } \text { Int }+\varepsilon_{i t}
\end{aligned}
$$

where $i$ refers to the firm and $t$ to the year. $\beta_{0}$ is the intercept and $\beta_{1-13}$ are the slope coefficients of firm risk measures and control variables. $R D$ and $I S$ represent the risk disclosure and income smoothing variables, respectively, which were discussed in the previous section. The risk measures as discussed in the previous section include: Beta, Leverage, Solvency, Liquidity, and Op_Risk. All variables are defined in Appendix 2.

We include several control variables that have been shown in the literature to be associated with risk disclosure and income smoothing including risk-adjusted returns $(R A R)$, firm size (Size), firm growth (Growth), firm profitability (Profitability), dividend payout (Dividend) and US-cross listing (Cross_Listing) (Michelson et al., 1995; Lang et al., 2003; Linsley and Shrives, 2006; Abraham and Cox, 2007; Miihkinen, 2012; Campbell et al., 2014; Liu and Espahbodi, 2014; Elshandidy et al., 2018). We also include the proportion of independent directors on the board (Ind_Directors) and analyst following (Analysts) representing internal and external monitoring (Gul and Leung, 2004; Kao and Chen, 2004; Huang et al., 2009; Ntim et al., 2013; Chen et al., 2017; Yu et al., 2018). Finally, we include industry and year fixed effects using dummy variables to control for changing microeconomic factors across time and industries. We estimate robust standard errors clustered at firm level to control for heteroscedasticity and serial correlation problems. All control variables are defined in Appendix 2.

\section{Empirical results}

\subsection{Descriptive statistics}

Panel A of Table 1 reports the descriptive statistics of the study variables. The table shows that the mean natural logarithm of the risk disclosure measure, $R D$, is 5.5 which is approximately equivalent to 282 risk-related statements disclosed in UK firms' annual reports. With respect to 
$I S$, the average value is -1.27 indicating that firms on average exhibit higher volatility in operating income as compared to operating cash flows.

Our sample has a mean value of systematic risk (Beta) of 1.02, suggesting that firms in our sample are more risky than average. The mean leverage risk is 0.97 and that of solvency risk is 0.73 . The mean liquidity risk is 0.97 , equivalent to a current ratio that is slightly above one (1.03). Operational risk has a mean value of 0.03 .

Panel B of Table 1 presents pairwise Pearson and Spearman correlations for the study variables. The coefficients for all pairs of the independent variables are below 0.8, thus indicating no multicollinearity problems. Similarly, Variance Inflation Indicators (untabulated) are below 10 for all independent variables, thus confirming that our model is not affected by multicollinearity (Hair et al., 2006). The table indicates a significant negative correlation between risk disclosure and income smoothing (Spearman correlation coefficient $=-0.16)$, thus suggesting a trade-off between both reporting choices. Also, leverage risk is significantly positively correlated with risk disclosure and income smoothing. We also find that risk disclosure is negatively related to liquidity risk, but positively related to systematic risk (Beta). In addition, we find a positive association between $I S$ and operational risk.

\section{[Insert Table 1 about here]}

\subsection{Empirical results}

We present our main tests in Table 2. The results in column 1 show that financial risk measures Leverage and Solvency are significantly and positively related to risk disclosure $\left(\beta_{2}=0.063\right.$ and $\beta_{3}=0.026$, both significant at the $1 \%$ level) similar to findings in prior research (e.g., Marshall and Weetman, 2007; Elshandidy et al., 2013; Khlif and Hussainey, 2016). We also find that liquidity risk (Liquidity) is negatively associated with risk disclosure $\left(\beta_{4}=-0.139\right.$, significant at the $1 \%$ level). These confirm our first hypothesis $\left(\mathrm{H}_{1}\right)$.

In column 2, we find a significant positive association between financial risk and income smoothing, which provides support to our second hypothesis $\left(\mathrm{H}_{2}\right)$. Specifically, we find that Leverage and Solvency are significantly and positively related to income smoothing $\left(\beta_{2}=0.076\right.$ and $\beta_{3}=0.068$, significant at the $10 \%$ and $5 \%$ levels, respectively). This is in line with prior studies which find that smoothing reduces the debt cost of capital hence mitigating the probability of 
breaching debt covenants and costly renegotiations (Gassen and Fülbier, 2015; Amiram and Owens, 2018). We also find a positive association between operational risk ( $\left.O p \_R i s k\right)$ and income smoothing $\left(\beta_{5}=9.096\right.$, significant at the $1 \%$ level), confirming $\mathrm{H}_{2}$. In terms of the control variables, significant variables include RAR, Size, Profitability, and Analysts.

The findings in both columns 1 and 2 indicate that as financial risk increases, firms report higher levels of smoothed income and risk information in a complementary way. This could be in order to dampen the disclosure tone of firms' financial risk with smooth income so that firms do not appear as risky as the risk disclosures might imply. Hence, we conclude that highly leveraged firms are more likely to complement risk disclosures with smoothed income in order to reduce financial statement users' risk perceptions. The results are consistent with our third hypothesis $\left(\mathrm{H}_{3}\right)$ indicating that there is a complementary association between risk disclosure and income smoothing.

\section{[Insert Table 2 about here]}

In panel B of Table 2, we examine the correlation between the error terms of Equations (1) and (2). We use the Breusch-Pagan test of independence of residuals and find this to be significant. The correlation coefficient between the residuals of risk disclosure (RD_Res) and income smoothing (IS_Res) is significantly negative, at the 1\% level (correlation coefficient $=-0.096$ ). This provides support for a substitutive association between risk disclosure and income smoothing. The residuals in Equation (1) reflect the unexplained portion of the variation in risk disclosure (RD_Res) which is likely being substituted with the unexplained portion of the variation in income smoothing (IS_Res), the residuals in Equation (2). Thus, the results provide evidence that firms in some cases trade-off between the levels of risk reporting and income smoothing. The substitution effect results from other incentives that are not explained by the firm risk profile and other firm characteristics included in the model. Perhaps, these incentives relate to managers' compensation motives which are beyond the scope of this study.

The results in column 3 use our alternative measure of income smoothing (IS_Corr) as dependent variable in Equation (2). The results are similar, suggesting that firms use risk disclosure and income smoothing as complements when leverage risk increases $\left(\beta_{2}=0.042\right.$, significant at the10\% level in column 3). Also, the correlation between the error terms (RD_Res) and (IS_Corr_Res) in panel $\mathrm{B}$ of Table 2 is significantly negative at the $10 \%$ level (correlation coefficient $=-0.061$ ), 
thus, confirming the tradeoff between risk disclosure and income smoothing, driven by other incentives not explained by our model.

\section{Additional analyses and robustness tests}

In Table 3, we provide an alternative methodology to test the substitutive association between risk disclosure and income smoothing. The unexplained portion of the variation in income smoothing (IS_Res) could be endogenous to the levels of risk disclosure. Hence, we test this by including $I S \_R e s$ as an explanatory variable in Equation (1). Specifically, we re-estimate Equation (1) for risk disclosure using a pooled Ordinary Least Squares (OLS) regression including an additional variable (IS_Res) as follows:

$$
\begin{aligned}
& R D_{i t}=\beta_{0}+\beta_{1} I S \_ \text {Resit }+\beta_{2} \text { Beta }_{i t}+\beta_{3} \text { Leverage }_{i t}+\beta_{4} \text { Solvency }_{i t}+\beta_{5} \text { Liquidity }_{i t}+ \\
& \beta_{6} O p_{-} \text {Risk }_{i t}+\beta{ }_{7} \text { RAR }_{i t}+\beta{ }_{8} \text { Size }_{i t}+\beta{ }_{9} \text { Growth }_{i t}+\beta_{10} \text { Profitability }_{i t}+\beta_{11} \text { Dividendit }+ \\
& \beta_{12} \text { Cross_Listing }{ }_{i t}+\beta_{13} \text { Ind_Directors }{ }_{i t}+\beta_{14} \text { Analysts }_{i t}+\varepsilon_{i t}
\end{aligned}
$$

The results in Table 3 show that the coefficient on IS_Res is significantly and negatively related to risk disclosure $\left(\beta_{1}=-0.035\right.$, significant at the $1 \%$ level), which is consistent with the findings in Panel B of Table 2, that risk disclosure is inversely correlated with income smoothing. That is, unknown managerial incentives may result in a trade-off between both reporting choices.

[Insert Table 3 about here]

We extend the robustness tests by introducing the level of institutional ownership (the percentage of shares held by institutions $)^{3}$ as an additional control variable in Equations (1) and (2). Prior literature documents that institutional shareholders act as powerful stakeholders with monitoring roles that influence risk reporting (Ntim et al., 2013) and earnings smoothing practices (Yu et al., 2018). The results (untabulated) remain unchanged.

Our final robustness test addresses different levels of risk in firms. We re-estimate Equations (1) and (2) after segregating between high-risk and low-risk firms to examine whether the complementary/substitutive relationship holds at different risk levels. We consider a firm with Beta more (less) than one as a high-risk (low-risk) firm (See Elshandidy et al., 2013). Table 4 reports the results of the subsample analysis. Panel A shows that the results for high-risk firms are

\footnotetext{
${ }^{3}$ We re-estimate the regression for the years 2010-2015, because historical data for institutional ownership is not available on Bloomberg before 2010.
} 
similar to those reported in Table 2 for the entire sample with Leverage being the driver of the complementary association between risk disclosure and income smoothing $\left(\beta_{2}=0.060\right.$ and $\beta_{2}=$ 0.137 , including $R D$ and $I S$ as dependent variables, respectively, both significant at the $1 \%$ level). As for low-risk firms, leverage risk is only positively correlated with risk disclosure $\left(\beta_{2}=0.071\right.$, significant at the $1 \%$ level). Therefore, we conclude that high-risk firms are more likely to report jointly risk information and smooth income as their leverage risk increases in order to lower firm perceived credit risk. Moreover, panel B presents qualitatively similar results for the correlation of residuals between $I S \_R e s$ and $R D \_R e s$ for high-risk firms, but significant results for low-risk firms (correlation coefficient $=-0.106$ ), thus supporting the evidence of risk reporting and income smoothing being reported as substitutes.

\section{[Insert Table 4 about here]}

\section{Conclusion}

In this study, we examine whether risk disclosure and income smoothing are used as complements or substitutes in relation to various firm risk measures. We test the associations by estimating a seemingly unrelated regression model to determine the nature of the association between both reporting choices with respect to firm risk and other firm-specific characteristics. We find that as financial risk increases, firms have more incentives to report incremental levels of risk disclosure and smoother earnings. Firms are likely to use both reporting choices as complements for several reasons. First, to reduce perceived default risk including expected cost of debt. Second, to meet UK regulatory risk reporting requirements regarding financial risk and risk management controls. Third, to signal higher risk management abilities compared to other firms with lower levels of risk disclosure and volatile earnings. Moreover, we find that while the level of risk disclosure is negatively associated with liquidity risk, the extent of income smoothing is positively associated with operational risk. We also find that there is a substitutive relation between risk disclosure and income smoothing for other drivers unexplained by firm riskiness and firm-level characteristics.

These findings are important to regulators, investors and boards of directors through highlighting the alternative reporting strategies that firms with high risk can choose between. The results indicate that regulators may need to consider further regulation on UK firms' smoothing decisions and risk reporting. The risk disclosures should be subject to external audits in order to ensure that 
disclosed information is relevant to the underlying firm risk profile, specifically to systematic, liquidity, and operational risks.

We do not consider other factors such as managerial optimism, managerial financial incentives and analysts' earnings forecasts which might influence the association between risk disclosure and income smoothing and hence this may be a limitation of the current study. These drivers can be considered as potential avenues for future research in examining the substitutive relation between both reporting choices. Also, our measurement of risk disclosure does not consider the quality of the textual risk information disclosed in UK firms' annual reports. Future research may develop a quantitative measure for the disclosure quality of risk reporting in the UK and hence investigate more than one dimension of textual risk disclosure in relation to firm risk and income smoothing. Also, further work may build on insights concerning the complementary relation between risk disclosure and income smoothing by examining the economic consequences of this relation on capital providers' perceptions of firm risk and expected cost of capital. 


\section{References}

Abdullah, M., Abdul Shukor, Z., Mohamed, Z.M. and Ahmad, A. (2015), "Risk management disclosure: A study on the effect of voluntary risk management disclosure toward firm value", Journal of Applied Accounting Research, Vol. 16 No. 3, pp. 400-432.

Abernethy, M. A., Dekker, H. C. and Schulz, A. K. D. (2015), "Are employee selection and incentive contracts complements or substitutes?", Journal of Accounting Research, Vol. 53 No. 4, pp. 633-668.

Abraham, S. and Cox, P. (2007), "Analysing the determinants of narrative risk information in UK FTSE 100 annual reports", The British Accounting Review, Vol. 39 No. 3, pp. 227-248.

Abraham, S. and Shrives, P.J. (2014), "Improving the relevance of risk factor disclosure in corporate annual reports", The British Accounting Review, Vol. 46 No. 1, pp. 91-107.

Amiram, D. and Owens, E. (2018), "Sign reversal in the relationship between income smoothing and cost of debt", Journal of Business Finance \& Accounting, Vol. 45 No.1-2, pp. 40-71.

Athanasakou, V. and Hussainey, K. (2014), "The perceived credibility of forward-looking performance disclosures", Accounting and Business Research, Vol. 44 No.3, pp. 227-259.

Beattie, V., Brown, S., Ewers, D., John, B., Manson, S., Thomas, D. and Turner, M. (1994), "Extraordinary items and income smoothing: A positive accounting approach", Journal of Business Finance \& Accounting, Vol. 21 No. 6, pp. 791-811.

Campbell, J. L., Chen, H., Dhaliwal, D. S., Lu, H. M. and Steele, L. B. (2014), "The information content of mandatory risk factor disclosures in corporate filings", Review of Accounting Studies, Vol. 19 No. 1, pp. 396-455.

Carlson, S. J. and Bathala, C. T. (1997), "Ownership differences and firms' income smoothing behavior", Journal of Business Finance \& Accounting, Vol. 24 No. 2, pp. 179-196.

Cassell, C.A., Myers, L.A. and Seidel, T.A. (2015), "Disclosure transparency about activity in valuation allowance and reserve accounts and accruals-based earnings management", Accounting, Organizations \& Society, Vol. 46, pp. 23-38.

Chaney, P.K. and Lewis, C.M. (1995), "Earnings management and firm valuation under asymmetric information", Journal of Corporate Finance, Vol. 1 No. 3-4, pp. 319-345.

Chen, C., Kim, J.B. and Yao, L. (2017), "Earnings smoothing: Does it exacerbate or constrain stock price crash risk?", Journal of Corporate Finance, Vol. 42, pp. 36-54.

Chih, H.L., Shen, C.H. and Kang, F.C. (2008), "Corporate social responsibility, investor protection and earnings management: some international evidence”, Journal of Business Ethics, Vol. 79, pp. 179-198.

Companies Act (2006), "Her majesty's stationery office, 2006", available at: http://www.legislation.gov.uk/ukpga/2006/46/part/15/chapter/4A.

Cox, C. (1985), "Further Evidence on the Representativeness of Management Earnings Forecasts", The Accounting Review, Vol. 60 No.4, pp. 692-701.

Dobler, M. (2008), "Incentives for risk reporting - A discretionary disclosure and cheap talk approach", The International Journal of Accounting, Vol. 43 No. 2, pp. 184-206.

Dobler, M., Lajili, K. and Zéghal, D. (2011), "Attributes of corporate risk disclosure: an international investigation in the manufacturing sector", Journal of International Accounting Research, Vol. 10 No. 2, pp. 1-22.

Dye, R. A. (1988), "Earnings management in an overlapping generations model", Journal of Accounting research, Vol. 26 No. 2, pp. 195-235. 
Elgammal, M.M., Hussainey, K. and Ahmed, F. (2018), "Corporate governance and voluntary risk and forward-looking disclosures", Journal of Applied Accounting Research, Vol. 19 No. 4, pp. 592-607.

Elshandidy, T., Fraser, I. and Hussainey, K. (2013), “Aggregated, voluntary, and mandatory risk disclosure incentives: Evidence from UK FTSE all-share companies”, International Review of Financial Analysis, Vol. 30, pp. 320-333.

Elshandidy, T., Fraser, I. and Hussainey, K. (2015), "What drives mandatory and voluntary risk reporting variations across Germany, UK and US?", The British Accounting Review, Vol. 47 No. 4, pp. 376-394.

Elshandidy, T., Neri, L. and Guo, Y. (2018), "Determinants and impacts of risk disclosure quality: Evidence from China", Journal of Applied Accounting Research, Vol. 19 No. 4, pp. 518-536.

Elzahar, H. and Hussainey, K. (2012), "Determinants of narrative risk disclosures in UK interim reports", The Journal of Risk Finance, Vol. 13 No. 2, pp. 133-147.

Erickson, D., Hewitt, M. and Maines, L.A. (2017), "Do investors perceive low risk when earnings are smooth relative to the volatility of operating cash flows? Discerning opportunity and incentive to report smooth earnings", The Accounting Review, Vol. 92 No. 3, pp.137-154.

Fama, E. F. and Jensen, M. C. (1983), "Separation of ownership and control", The journal of law and Economics, Vol. 26 No. 2, pp. 301-325.

Francis, J., Nanda, D. and Olsson, P. (2008), "Voluntary disclosure, earnings quality, and cost of capital", Journal of Accounting Research, Vol. 46 No. 1, pp. 53-99.

FRC (2014), "Guidance on Risk Management, Internal Control and Related Financial and Business Reporting", Financial Reporting Council, London.

Gassen, J., and Fülbier, R.U. (2015), "Do creditors prefer smooth earnings? Evidence from European private firms", Journal of International Accounting Research, Vol. 14 No. 2, pp. 151-180.

Graham, J. R., Harvey, C. R. and Rajgopal, S. (2005), "The economic implications of corporate financial reporting", Journal of Accounting \& Economics, Vol. 40 No.1, pp. 3-73.

Grant, J., Markarian, G. and Parbonetti, A. (2009), "CEO Risk-related incentives and income smoothing", Contemporary Accounting Research, Vol. 26 No. 4, pp. 1029-1065.

Gul, F. and Leung, S. (2004), "Board leadership, outside directors' expertise and voluntary corporate disclosures", Journal of Accounting and Public Policy, Vol. 23 No. 5, pp. 351379.

Hair, J. F., Black, W. C., Babin, B. J., Anderson, R. E. and Tatham, RL. (2006), Multivariate Data Analysis, 6th ed., Pearson Prentice Hall, Upper Saddle, NJ.

Hribar, P. and Collins, D. W. (2002), "Errors in estimating accruals: Implications for empirical research", Journal of Accounting Research, Vol. 40 No. 1, pp. 105-134.

Huang, P., Zhang, Y., Deis, D.R. and Moffitt, J.S. (2009), "Do artificial income smoothing and real income smoothing contribute to firm value equivalently?", Journal of Banking \& Finance, Vol. 33 No. 2, pp. 224-233.

Hussainey, K., Schleicher, T. and Walker, M. (2003), "Undertaking large-scale disclosure studies when AIMR-FAF ratings are not available: the case of prices leading earnings", Accounting and Business Research, Vol. 33 No. 4, pp. 275-294.

Jans, M., Orens, R. and Lybaert, N. (2008), "The relation between disclosure quality, income smoothing and earnings' timeliness", Working paper, Hasselt University, available at: https://doclib.uhasselt.be/dspace/bitstream/1942/7871/1/tekst.pdf.

Jo, J. and Kim, Y. (2007), "Disclosure frequency and earnings management”, Journal of Financial Economics, Vol. 84 No. 2, pp. 561-590 
Jorgensen, B.N. and Kirschenheiter, M.T. (2003), "Discretionary risk disclosures", The Accounting Review, Vol. 78 No. 2, pp. 449-469.

Kao, L. and Chen, A. (2004), "The effects of board characteristics on earnings management", Corporate Ownership \& Control, Vol. 1 No. 3, pp. 96-107.

Kasznik, R. (1999), "On the association between voluntary disclosure and earnings management", Journal of Accounting Research, Vol. 37 No. 1, pp. 57-81.

Katmon, N. and Al Farooque, O. (2017), "Exploring the impact of internal corporate governance on the relation between disclosure quality and earnings management in the UK listed companies", Journal of Business Ethics, Vol. 142 No. 2, pp. 345-367.

Khlif, H. and Hussainey, K. (2016), "The association between risk disclosure and firm characteristics: a meta-analysis", Journal of Risk Research, Vol. 19 No. 2, pp.181-211.

Kravet, T. and Muslu, V. (2013), "Textual risk disclosures and investors' risk perceptions", Review of Accounting Studies, Vol. 18 No. 4, pp. 1088-1122.

Lang, M., Raedy, J.S. and Yetman, M.H. (2003), "How representative are firms that are cross-listed in the United States? An analysis of accounting quality", Journal of Accounting Research, Vol. 41 No. 2, pp. 363-386.

Lapointe-Antunes, P., Cormier D., Magnan, M. and Gay-Angers, S. (2006), “On the relationship between voluntary disclosure, earnings smoothing and the value-relevance of earnings: The case of Switzerland", European Accounting Review, Vol. 15 No. 4, pp. 465-505.

Leftwich, R. W., Watts, R. L. and Zimmerman, J. L. (1981), "Voluntary corporate disclosure: The case of interim reporting", Journal of Accounting Research, pp. 50-77.

Leuz, C., Nanda, D. and Wysocki, P. D. (2003), "Earnings management and investor protection: An international comparison", Journal of Financial Economics, Vol. 69 No. 3, pp. 505527.

Li, F. (2006), 'Do stock market investors understand the risk Sentiment of corporate annual reports?', Working Paper, Shanghai Jiaotong University, available at: http://papers.ssm.com/sol3/papers.cfm?abstract id=898181.

Linsley, P. M. and Shrives, P. J. (2006), "Risk reporting: A study of risk disclosures in the annual reports of UK companies", The British Accounting Review, Vol. 38 No. 4, pp. 387-404.

Linsley, P. M. and Shrives, P. J. (2005), "Examining risk reporting in UK public companies", The Journal of Risk Finance, Vol. 6 No. 4, pp. 292-305.

Liu, N. and Espahbodi, R. (2014), "Does dividend policy drive earnings smoothing?", Accounting Horizons, Vol. 28 No. 3, pp. 501-528.

Lobo, G.J. and Zhou, J. (2001), "Disclosure quality and earnings management", Asia-Pacific Journal of Accounting \& Economics, Vol. 8 No. 1, pp. 1-20.

Markarian, G. and Gill-de-Albornoz, B. (2012), "Income smoothing and idiosyncratic volatility", Working Paper, WHU - Otto Beisheim School of Management, available at: http://papers.ssrn.com/sol3/papers.cfm?abstract_id=1270826.

Marshall, A. and Weetman, P. (2007), "Modelling transparency in disclosure: the case of foreign exchange risk management", Journal of Business Finance \& Accounting, Vol. 34 No. 5-6, pp. 705-739.

Michelson, S. E., Jordan-Wagner, J. and Wootton, C. W. (1995), “A market based analysis of income smoothing", Journal of Business Finance \& Accounting, Vol. 22 No.8, pp. 11791193.

Miihkinen, A. (2012), "What drives quality of firm risk disclosure? The impact of a national disclosure standard and reporting incentives under IFRS", The International Journal of Accounting, Vol. 47 No. 4, pp. 437-468. 
Mouselli, S., Jaafar, A. and Hussainey, K. (2012), "Accruals quality vis-à-vis disclosure quality: Substitutes or complements?", The British Accounting Review, Vol. 44 No.1, pp. 36-46.

Ntim, C. G., Lindop, S. and Thomas, D. A. (2013), "Corporate governance and risk reporting in South Africa: A study of corporate risk disclosures in the pre-and post-2007/2008 global financial crisis periods", International Review of Financial Analysis, Vol. 30, pp.363-383.

Shaw, K.W. (2003), "Corporate disclosure quality, earnings smoothing, and earnings' timeliness", Journal of Business Research, Vol. 56 No. 12, pp. 1043-1050.

Shen, C.H. and Chih, H.L. (2005), "Investor protection, prospect theory, and earnings management: An international comparison of the banking industry”, Journal of Banking \& Finance, Vol. 29 No. 10, pp. 2675-2697.

Tseng, L. J. and Lai, C. W. (2007), "The relationship between income smoothing and company profitability: An empirical study", International Journal of Management, Vol. 24 No. 4, pp. 727-733.

Tucker, J.W. (2015), “The relation between disclosure quality and reporting quality: A discussion of Cassell, Myers, and Seidel (2015)", Accounting, Organizations \& Society, Vol. 46, pp. 39-43.

Yu, K., Hagigi, M. and Stewart, S.D. (2018), "Income smoothing may result in increased perceived riskiness: Evidence from bid-ask spreads around loss announcements", Journal of Corporate Finance, Vol. 48, pp. 442-459. 


\section{Table 1}

Sample Statistics

Panel A: Descriptive statistics (814 firm-year observations 2005-2015)

\begin{tabular}{lccccc}
\hline Variable & Mean & $\begin{array}{c}\text { Lower } \\
\text { Quartile }\end{array}$ & Median & $\begin{array}{c}\text { Upper } \\
\text { Quartile }\end{array}$ & $\begin{array}{c}\text { Standard } \\
\text { Deviation }\end{array}$ \\
\hline$R D$ & 5.507 & 5.142 & 5.529 & 5.878 & 0.529 \\
IS & -1.265 & -1.493 & -0.987 & -0.698 & 0.901 \\
Beta & 1.017 & 0.610 & 0.890 & 1.320 & 0.571 \\
Leverage & 0.970 & 0.331 & 0.588 & 1.119 & 1.278 \\
Solvency & 0.734 & 0.252 & 0.486 & 0.891 & 1.039 \\
Liquidity & 0.969 & 0.633 & 0.824 & 1.200 & 0.553 \\
Op_Risk & 0.033 & 0.015 & 0.025 & 0.041 & 0.027 \\
RAR & 0.411 & 0.000 & 0.366 & 0.802 & 0.532 \\
Size & 9.057 & 8.028 & 8.894 & 10.046 & 1.353 \\
Growth & 3.891 & 1.738 & 2.836 & 4.714 & 4.720 \\
Profitability & 0.139 & 0.092 & 0.125 & 0.179 & 0.082 \\
Dividend & 0.585 & 0.258 & 0.442 & 0.622 & 0.843 \\
Cross_Listing & 0.378 & 0.000 & 0.000 & 1.000 & 0.485 \\
Ind_Directors & 0.621 & 0.538 & 0.625 & 0.700 & 0.124 \\
Analysts & 2.998 & 2.773 & 3.045 & 3.258 & 0.379 \\
\hline
\end{tabular}


Table 1 (Continued)

Panel B: Pairwise Spearman (Pearson) correlations above (below) the diagonal

\begin{tabular}{|c|c|c|c|c|c|c|c|c|c|c|c|c|c|c|c|}
\hline & (1) & (2) & (3) & (4) & (5) & (6) & $(7)$ & $(8)$ & (9) & (10) & (11) & (12) & (13) & (14) & (15) \\
\hline (1) $R D$ & & -0.163 & 0.147 & 0.076 & 0.050 & -0.048 & -0.017 & 0.008 & 0.436 & 0.021 & -0.026 & 0.064 & 0.202 & 0.412 & 0.451 \\
\hline (2) $I S$ & -0.187 & & -0.039 & 0.105 & 0.092 & 0.005 & 0.212 & 0.081 & -0.157 & 0.156 & 0.012 & 0.149 & -0.131 & -0.151 & -0.209 \\
\hline (3) Beta & 0.156 & -0.055 & & 0.016 & -0.019 & 0.037 & -0.078 & 0.015 & 0.107 & 0.067 & -0.008 & 0.073 & 0.035 & 0.099 & 0.160 \\
\hline (4) Leverage & 0.063 & 0.059 & 0.032 & & 0.677 & 0.294 & -0.218 & -0.024 & 0.072 & 0.352 & -0.017 & 0.279 & -0.039 & -0.055 & -0.129 \\
\hline (5) Solvency & 0.009 & 0.083 & -0.026 & 0.214 & & 0.335 & -0.276 & 0.034 & 0.037 & 0.245 & -0.023 & 0.288 & -0.100 & -0.019 & -0.067 \\
\hline (6) Liquidity & -0.150 & -0.023 & 0.011 & 0.115 & 0.182 & & -0.280 & 0.055 & 0.287 & 0.081 & -0.013 & 0.254 & 0.157 & 0.009 & 0.153 \\
\hline (7) $O p \_R i s k$ & -0.011 & 0.221 & -0.020 & -0.096 & -0.127 & -0.236 & & 0.018 & -0.241 & 0.199 & 0.326 & -0.265 & -0.084 & -0.098 & -0.064 \\
\hline (8) $R A R$ & -0.008 & 0.160 & 0.038 & -0.022 & 0.047 & 0.024 & 0.029 & & -0.078 & 0.488 & 0.303 & 0.163 & -0.034 & -0.001 & -0.078 \\
\hline (9) Size & 0.448 & -0.161 & 0.096 & 0.008 & 0.017 & 0.220 & -0.198 & -0.090 & & -0.242 & -0.145 & 0.126 & 0.460 & 0.397 & 0.509 \\
\hline (10) Growth & -0.021 & 0.065 & 0.050 & 0.595 & 0.125 & 0.020 & 0.121 & 0.255 & -0.180 & & 0.516 & 0.147 & -0.002 & -0.077 & -0.078 \\
\hline (11) Profitability & -0.055 & 0.181 & 0.024 & 0.040 & -0.026 & -0.049 & 0.275 & 0.314 & -0.127 & 0.375 & & 0.020 & 0.105 & 0.000 & 0.063 \\
\hline (12) Dividend & 0.034 & 0.031 & 0.012 & 0.087 & 0.031 & 0.051 & -0.080 & 0.022 & 0.022 & -0.019 & -0.058 & & 0.093 & 0.056 & 0.032 \\
\hline (13) Cross_Listing & 0.198 & -0.106 & 0.046 & 0.022 & -0.054 & 0.215 & -0.111 & -0.035 & 0.486 & 0.009 & 0.064 & -0.016 & & 0.361 & 0.334 \\
\hline (14) Ind_Directors & 0.414 & -0.146 & 0.110 & -0.084 & -0.064 & 0.030 & $-\mathbf{0 . 0 9 7}$ & 0.008 & 0.435 & -0.074 & -0.001 & 0.023 & 0.362 & & 0.386 \\
\hline (15) Analysts & 0.488 & -0.165 & 0.175 & -0.068 & 0.002 & 0.116 & -0.104 & -0.060 & 0.521 & 0.011 & 0.039 & -0.040 & 0.308 & 0.375 & \\
\hline
\end{tabular}

All variables are defined in Appendix 2.

Bold numbers in Panel B indicate statistical significance at $10 \%$ or lower using a two-tailed test. 
Table 2

Association between Risk Disclosure, Income Smoothing and Firm Risk

The table shows the coefficient estimates (z-statistics) from seemingly unrelated regressions based on 814 firmyear observations of the form:

$R D_{i t}=\beta_{0}+\beta_{1}$ Beta $_{i t}+\beta_{2}$ Leverage $_{i t}+\beta_{3}$ Solvency $_{i t}+\beta_{4}$ Liquidity $_{i t}+\beta_{5}$ Op_Risk $_{i t}+\beta_{6} R A R_{i t}+\beta_{7}$ Size $_{i t}+\beta_{8}$ Growth $_{i t}+$ $\beta_{9}$ Profitability $_{i t}+\beta_{10}$ Dividend $_{i t}+\beta_{11}$ Cross_Listing $_{i t}+\beta_{12}$ Ind_Directors $_{i t}+\beta_{13}$ Analysts $_{i t}+\varepsilon_{i t}$

$I S_{i t}\left(I_{S}\right.$ Corr $\left._{i t}\right)=\beta_{0}+\beta_{1}$ Beta $_{i t}+\beta_{2}$ Leverage $_{i t}+\beta_{3}$ Solvency $_{i t}+\beta_{4}$ Liquidity $_{i t}+\beta_{5}$ Op_Risk $_{i t}+\beta_{6}$ RAR $_{i t}+\beta_{7}$ Size $_{i t}+$

$\beta_{8}$ Growth $_{i t}+\beta_{9}$ Profitability $_{i t}+\beta_{10}$ Dividend $_{i t}+\beta_{11}$ Cross_Listing $_{i t}+\beta_{12}$ Ind_Directors $_{i t}+\beta_{13}$ Analyst $_{i t}+\varepsilon_{i t}$

\begin{tabular}{|c|c|c|c|}
\hline \multicolumn{4}{|c|}{ Panel A: Seemingly Unrelated Regression Results } \\
\hline \multirow[t]{2}{*}{ Beta } & 0.001 & -0.018 & 0.054 \\
\hline & $(0.04)$ & $(-0.29)$ & $(1.18)$ \\
\hline \multirow[t]{2}{*}{ Leverage } & $0.063^{* * *}$ & $0.076^{*}$ & $0.042^{*}$ \\
\hline & $(6.10)$ & $(1.96)$ & $(1.80)$ \\
\hline \multirow[t]{2}{*}{ Solvency } & $0.026^{* * *}$ & $0.068^{* *}$ & 0.036 \\
\hline & $(2.62)$ & $(2.53)$ & $(1.43)$ \\
\hline \multirow[t]{2}{*}{ Liquidity } & $-0.139^{* * *}$ & -0.069 & 0.010 \\
\hline & $(-5.37)$ & $(-1.10)$ & $(0.18)$ \\
\hline \multirow[t]{2}{*}{$O p \_R i s k$} & 0.604 & $9.096^{* * *}$ & -0.881 \\
\hline & $(1.29)$ & $(6.94)$ & $(-0.75)$ \\
\hline \multirow[t]{2}{*}{$R A R$} & $-0.049^{*}$ & $0.289^{* * * *}$ & $-0.096^{*}$ \\
\hline & $(-1.96)$ & $(3.97)$ & $(-1.76)$ \\
\hline \multirow[t]{2}{*}{ Size } & $0.119^{* * *}$ & $0.067^{*}$ & -0.002 \\
\hline & $(9.08)$ & $(1.92)$ & $(-0.07)$ \\
\hline \multirow[t]{2}{*}{ Growth } & -0.004 & $-0.022^{*}$ & -0.002 \\
\hline & $(-0.92)$ & $(-1.81)$ & $(-0.28)$ \\
\hline \multirow[t]{2}{*}{ Profitability } & $0.004^{* *}$ & $0.013^{* *}$ & $0.008^{* *}$ \\
\hline & (2.19) & $(2.38)$ & $(2.06)$ \\
\hline \multirow[t]{2}{*}{ Dividend } & 0.010 & 0.018 & -0.022 \\
\hline & $(0.62)$ & $(0.49)$ & $(-0.59)$ \\
\hline \multirow[t]{2}{*}{ Cross_Listing } & -0.035 & -0.020 & -0.031 \\
\hline & $(-1.28)$ & $(-0.25)$ & $(-0.47)$ \\
\hline \multirow[t]{2}{*}{ Ind_Directors } & 0.099 & -0.065 & $0.478^{* *}$ \\
\hline & $(0.89)$ & $(-0.25)$ & (1.97) \\
\hline \multirow[t]{2}{*}{ Analysts } & $0.132^{* * *}$ & $-0.371^{* * *}$ & 0.069 \\
\hline & $(3.16)$ & $(-3.29)$ & $(0.68)$ \\
\hline Industry Controls & Yes & Yes & Yes \\
\hline Year Controls & Yes & Yes & Yes \\
\hline Chi-Square & $1806.37 * * *$ & $210.84 * * *$ & $73.84^{* * *}$ \\
\hline $\mathrm{R}^{2}$ & $68.94 \%$ & $20.57 \%$ & $8.32 \%$ \\
\hline
\end{tabular}

Panel B: Correlation Matrix of Residuals

\begin{tabular}{llc} 
& RD_Res & RD_Res \\
\hline IS_Res & $-0.096^{* * *}$ & $-0.061^{*}$ \\
IS_Corr_Res & & 3.034 \\
\hline Breusch-Pagan Chi-Square & $7.423^{* * *}$ & .
\end{tabular}

RD_Res is the residual value from Equation (1) which is the unexplained portion of risk disclosure; IS_Res (IS_Corr_Res) is the residual value from Equation (2) which is the unexplained portion of income smoothing; all remaining variables are defined in Appendix 2.

$*, * *$, and $* * *$ indicate significance at $10 \%, 5 \%$ and $1 \%$, respectively (two-tailed). 
Table 3

\section{Pooled Regressions}

The table shows the coefficient estimates (t-statistics) from Pooled OLS regressions based on 814 firm-year observations of the form:

$R D_{i t}=\beta_{0}+\beta_{1} I S_{-}$Res $_{i t}+\beta_{2}$ Beta $_{i t}+\beta_{3}$ Leverage $_{i t}+\beta_{4}$ Solvency $_{i t}+\beta_{5}$ Liquidity $_{i t}+\beta_{6} O P_{-}$Risk $_{i t}+\beta_{7}$ RAR $_{i t}+\beta_{8}$ Size $_{i t}+$ $\beta_{9}$ Growth $_{i t}+\beta_{10}$ Profitability $_{i t}+\beta_{11}$ Dividend $_{i t}+\beta_{12}$ Cross_Listing $_{i t}+\beta_{13}$ Ind_Directors ${ }_{i t}+\beta_{14}$ Analysts ${ }_{i t}+\varepsilon_{i t}$ (3)

\begin{tabular}{|c|c|}
\hline & $R D$ \\
\hline IS_Res & $\begin{array}{c}-0.035^{* * *} \\
(2.62)\end{array}$ \\
\hline Beta & $\begin{array}{l}0.001 \\
(0.04)\end{array}$ \\
\hline Leverage & $\begin{array}{c}0.063^{* * *} \\
(6.20)\end{array}$ \\
\hline Solvency & $\begin{array}{c}0.026^{* * *} \\
(2.64)\end{array}$ \\
\hline Liquidity & $\begin{array}{c}-0.139^{* * *} \\
(5.73)\end{array}$ \\
\hline$O p \_R i s k$ & $\begin{array}{l}0.604 \\
(1.27)\end{array}$ \\
\hline$R A R$ & $\begin{array}{c}-0.049^{* *} \\
(2.04)\end{array}$ \\
\hline Size & $\begin{array}{c}0.119^{* * *} \\
(9.25)\end{array}$ \\
\hline Growth & $\begin{array}{c}-0.004 \\
(0.99)\end{array}$ \\
\hline Profitability & $\begin{array}{c}0.004^{* *} \\
(2.08)\end{array}$ \\
\hline Dividend & $\begin{array}{c}0.01 \\
(0.65)\end{array}$ \\
\hline Cross_Listing & $\begin{array}{l}-0.035 \\
(-1.23)\end{array}$ \\
\hline Ind_Directors & $\begin{array}{l}0.099 \\
(0.92)\end{array}$ \\
\hline Analysts & $\begin{array}{c}0.132^{\text {**** }} \\
(3.1)\end{array}$ \\
\hline Industry Controls & Yes \\
\hline Year Controls & Yes \\
\hline F-Statistic & $66.62 * * *$ \\
\hline
\end{tabular}

$I S \_R e s$ is the residual from Equation (2) which is the unexplained portion of income smoothing; all remaining variables are defined in Appendix 2.

$*, * *$, and $* * *$ indicate significance at $10 \%, 5 \%$ and $1 \%$, respectively (two-tailed). 


\section{Table 4}

\section{Subsample Analysis for High-risk and Low-risk Firms}

The table shows the coefficient estimates (z-statistics) from seemingly unrelated regressions based on 357 high-risk and 457 low-risk firm-year observations of the form:

$R D_{i t}=\beta_{0}+\beta_{1}$ Beta $_{i t}+\beta_{2}$ Leverage $_{i t}+\beta_{3}$ Solvency $_{i t}+\beta_{4}$ Liquidity $_{i t}+\beta_{5} O p_{-}$Risk $_{i t}+\beta_{6} R A R_{i t}+\beta_{7}$ Size $_{i t}+\beta_{8}$ Growth $_{i t}+$ $\beta_{9}$ Profitability $_{i t}+\beta_{10}$ Dividend $_{i t}+\beta_{11}$ Cross_Listing $_{i t}+\beta_{12}$ Ind_Directors $_{i t}+\beta_{13}$ Analysts $_{i t}+\varepsilon_{i t}$ $I S_{i t}=\beta_{0}+\beta_{1}$ Beta $_{i t}+\beta_{2}$ Leverage $_{i t}+\beta_{3}$ Solvency $_{i t}+\beta_{4}$ Liquidity $_{i t}+\beta_{5}$ Op_Risk Rit $_{i}+\beta_{6} R A R_{i t}+\beta_{7}$ Size $_{i t}+\beta_{8}$ Growth $_{i t}+$ $\beta_{9}$ Profitability $_{i t}+\beta_{10}$ Dividend $_{i t}+\beta_{11}$ Cross_Listing $_{i t}+\beta_{12}$ Ind_Directors $_{i t}+\beta_{13}$ Analyst $_{i t}+\varepsilon_{i t}$

\begin{tabular}{|c|c|c|c|c|}
\hline & \multicolumn{2}{|c|}{ High-risk Firms } & \multicolumn{2}{|c|}{ Low-risk Firms } \\
\hline & $R D$ & $I S$ & $R D$ & $I S$ \\
\hline \multirow[t]{2}{*}{ Beta } & 0.053 & -0.069 & $0.172^{* * *}$ & $-0.446^{* * *}$ \\
\hline & $(1.25)$ & $(-0.50)$ & (2.64) & $(-2.38)$ \\
\hline \multirow[t]{2}{*}{ Leverage } & $0.060^{* * *}$ & $0.137^{* * *}$ & $0.071^{* * *}$ & 0.006 \\
\hline & (3.76) & (2.91) & (4.23) & $(0.13)$ \\
\hline \multirow[t]{2}{*}{ Solvency } & $0.037^{*}$ & 0.063 & 0.017 & $0.071^{* * *}$ \\
\hline & $(1.69)$ & $(1.30)$ & $(1.59)$ & $(2.49)$ \\
\hline \multirow[t]{2}{*}{ Liquidity } & $-0.138^{* * * *}$ & -0.088 & $-0.147^{* * *}$ & -0.077 \\
\hline & $(-3.27)$ & $(-0.87)$ & $(-5.09)$ & $(-1.05)$ \\
\hline \multirow[t]{2}{*}{ Op_Risk } & 0.332 & $9.559^{* * *}$ & 0.882 & $8.729^{* * *}$ \\
\hline & $(0.45)$ & (4.15) & $(1.26)$ & $(5.37)$ \\
\hline \multirow[t]{2}{*}{$R A R$} & -0.035 & $0.393^{* * *}$ & -0.043 & $0.202^{* * *}$ \\
\hline & $(-0.80)$ & (2.97) & $(-1.47)$ & $(2.05)$ \\
\hline \multirow[t]{2}{*}{ Size } & $0.100^{* * *}$ & 0.055 & $0.133^{* * *}$ & 0.070 \\
\hline & (4.22) & $(0.83)$ & $(7.68)$ & $(1.55)$ \\
\hline \multirow[t]{2}{*}{ Growth } & -0.010 & $-0.051^{* * * *}$ & -0.001 & -0.004 \\
\hline & $(-1.53)$ & $(-2.62)$ & $(-0.13)$ & $(-0.29)$ \\
\hline \multirow[t]{2}{*}{ Profitability } & 0.003 & $0.022^{* *}$ & 0.004 & 0.007 \\
\hline & $(0.95)$ & $(2.52)$ & $(1.44)$ & $(0.95)$ \\
\hline \multirow[t]{2}{*}{ Dividend } & 0.013 & 0.078 & 0.012 & -0.014 \\
\hline & $(0.49)$ & (1.18) & $(0.55)$ & $(-0.31)$ \\
\hline \multirow[t]{2}{*}{ Cross_Listing } & -0.024 & 0.021 & -0.040 & -0.081 \\
\hline & $(-0.47)$ & $(0.17)$ & $(-1.05)$ & $(-0.76)$ \\
\hline \multirow[t]{2}{*}{ Ind_Directors } & 0.198 & -0.308 & 0.057 & 0.169 \\
\hline & $(1.24)$ & $(-0.79)$ & $(0.39)$ & $(0.43)$ \\
\hline \multirow[t]{2}{*}{ Analysts } & 0.048 & -0.102 & $0.194^{* * *}$ & $-0.542^{* * * *}$ \\
\hline & $(0.69)$ & $(-0.56)$ & $(3.33)$ & $(-3.62)$ \\
\hline Industry Controls & Yes & Yes & Yes & Yes \\
\hline Year Controls & Yes & Yes & Yes & Yes \\
\hline Chi-Square & $683.80 * * *$ & $128.87 * * *$ & $1247.49 * * *$ & $134.92 * * *$ \\
\hline$R^{2}$ & $65.70 \%$ & $26.52 \%$ & $73.19 \%$ & $22.79 \%$ \\
\hline
\end{tabular}

Panel B: Correlation Matrix of Residuals

RD_Res

\begin{tabular}{lll}
\hline IS_Res & -0.048 & -0.106 \\
\hline Breusch-Pagan Chi-Square & 0.808 & $5.162^{* *}$
\end{tabular}

$R D \_$Res is the residual value from Equation (1) which is the unexplained portion of risk disclosure; IS_Res is the residual from Equation (2) which is the unexplained portion of income smoothing; all remaining variables are defined in Appendix 2.

$*, * *$, and $* * *$ indicate significance at $10 \%, 5 \%$ and $1 \%$, respectively (two-tailed). 
Appendix 1

List of risk-related keywords used in study

\begin{tabular}{l} 
adverse* \\
affect \\
challeng* \\
could \\
detrimental \\
expect \\
expects \\
expos* \\
fail* \\
fluctuat* \\
impact* \\
influenc* \\
likely \\
may \\
might \\
possibl* \\
potential* \\
risk* \\
susceptible \\
threat \\
uncertain* \\
unexpect* \\
unhedge* \\
unlikely \\
unpredictable \\
variability \\
volatil* \\
\hline \\
* includes derivations of the word
\end{tabular} 


\section{Appendix 2}

Definition and Measurement of Variables

\begin{tabular}{|c|c|}
\hline Variable & Definition and Measurement \\
\hline \multicolumn{2}{|c|}{ Dependent Variables: } \\
\hline$R D$ & $\begin{array}{l}\text { Risk disclosure; the natural logarithm of the total number of sentences } \\
\text { containing at least one risk-related word }\end{array}$ \\
\hline$I S$ & $\begin{array}{l}\text { Income smoothing; the ratio of a firm's standard deviation of operating } \\
\text { income deflated by total assets divided by the standard deviation of its } \\
\text { cash flow from operations deflated by total assets, calculated over a } \\
\text { period of } 5 \text {-years. The measure is multiplied by }-1 \text {, so that higher values } \\
\text { indicate higher levels of income smoothing }\end{array}$ \\
\hline IS_Corr & $\begin{array}{l}\text { Alternative measure of income smoothing; the correlation between } \\
\text { changes in accounting accruals and changes in cash flows from } \\
\text { operations (both deflated by total assets), calculated over a period of } 5- \\
\text { years. The measure is multiplied by }-1 \text {, so that higher values indicate } \\
\text { higher levels of income smoothing }\end{array}$ \\
\hline \multicolumn{2}{|l|}{ Risk Measures: } \\
\hline Beta & $\begin{array}{l}\text { Systematic risk; calculated based on the market model using firms' } \\
\text { monthly stock returns and the value weighted market index, over a } \\
\text { period of } 5 \text {-years }\end{array}$ \\
\hline Leverage & Measure of firm financial risk; the ratio of total debt to total equity \\
\hline Solvency & $\begin{array}{l}\text { Measure of firm financial risk, the reciprocal of asset coverage ratio; } \\
\text { the difference between net assets and net liabilities divided by total } \\
\text { liabilities }\end{array}$ \\
\hline Liquidity & $\begin{array}{l}\text { Liquidity risk, the reciprocal of current ratio; total current assets } \\
\text { divided by total current liabilities }\end{array}$ \\
\hline Op_Risk & $\begin{array}{l}\text { Operational risk, the standard deviation of operating cash flows, } \\
\text { estimated using annual data over a period of } 5 \text {-years, deflated by total } \\
\text { assets }\end{array}$ \\
\hline \multicolumn{2}{|c|}{ Control Variables: } \\
\hline$R A R$ & $\begin{array}{l}\text { Sharpe ratio reflecting risk-adjusted returns; the excess market returns } \\
\text { divided by the standard deviation of monthly returns, over a period of } \\
5 \text {-years }\end{array}$ \\
\hline Size & Size; the natural logarithm of total assets \\
\hline Growth & Growth; the ratio of market value to book value of equity \\
\hline Profitability & $\begin{array}{l}\text { Profitability; the ratio of earnings before interest, taxes, depreciation } \\
\text { and amortization divided by total assets }\end{array}$ \\
\hline Dividend & $\begin{array}{l}\text { Dividend payout ratio; the proportion of net income distributed to } \\
\text { shareholders in the form of dividends }\end{array}$ \\
\hline Cross_Listing & $\begin{array}{l}\text { Dummy variable with a value of } 1 \text { for UK firms cross-listed on US } \\
\text { stock exchange, and } 0 \text { otherwise }\end{array}$ \\
\hline Ind_Directors & Proportion of independent directors on the board \\
\hline Analysts & Number of analysts following a firm \\
\hline
\end{tabular}

